\title{
Female Infanticide in 19th-Century India: A Genocide?
}

\author{
Pramod Kumar Srivastava \\ Department of Western History, University of Lucknow, Lucknow, India \\ Email: Srivastava_pk@lkouniv.ac.in
}

Received 15 September 2014; revised 19 October 2014; accepted 31 October 2014

Copyright (C) 2014 by author and Scientific Research Publishing Inc.

This work is licensed under the Creative Commons Attribution International License (CC BY). http://creativecommons.org/licenses/by/4.0/

(c) $\underset{\mathrm{EY}}{\text { (i) }}$ Open Access

\begin{abstract}
In post-colonial India the female foeticide, a practice evolved from customary female infanticide of pre-colonial and colonial period, committed though in separate incidents, has made it almost a unified wave of mass murder. It does not fulfil the widely accepted existing definition of genocide but the high rate of abortion of legitimate girl-foetus by Indian parents makes their crime a kind of group killing or genocide. The female foeticide in post-colonial India is not a modern phenomenon but was also prevalent in pre-colonial India since antiquity as female infanticide and the custom continued in the 19th century in many communities of colonial India, documentation of which are widely available in various archives. In spite of the Act of 1870 passed by the Colonial Government to suppress the practice, treating it a murder and punishing the perpetrators of the crime with sentence of death or transportation for life, the crime of murdering their girl children did not stop. During a period of five to ten years after the promulgation of the Act around 333 cases of female infanticide were tried and 16 mothers were sentenced to death, 133 to transportation for life and others for various terms of rigorous imprisonment in colonial India excluding British Burma and Assam where no such crime was reported. The present paper, on the basis of unpublished proceedings and files of Judicial and Criminal department of nineteenth century and published documents, presents a critical discussion on consideration of such unified wave of customary criminality as a sexually selective genocide, its concepts and location of female infanticide in selective areas dominated by specific patriarchal ethos of Hinduism alone, the religious and economic causes behind formation of a historically reliant peculiar Indian mind set, its nineteenth century encounter with legislative measures of astounded colonial state still responsible for continuation of such criminality in more sophisticated way with the help of modern technology, and historically reliant patriarchal mind set of post-colonial Indian state.
\end{abstract}

\section{Keywords}

Infanticide, Female Infanticide, Foeticide, Homicide, Gynecocracy 


\section{Introduction}

The intentional killing of girl-child because of the low value-religious and economic-associated with the daughter in comparison to a son may be defined as female infanticide. The use of modern day technology in ascertaining the sex of foetus to be aborted, if found to be fair, is not an uncommon criminality in contemporary urban and rural India. The modern female foeticide is a historically reliant custom evolved from the bizarre Hindu custom of female infanticide known since antiquity. Though a silent agreement existed among all the major members of the family, it was always mothers alleged to be convicted for the homicide after promulgation in 1870, an act prohibiting it during British colonialism. The undeclared massacre of fair sex was not unknown in the history of mankind but it is still prevailing in many parts of the world, especially India and China. The female infanticide is different than infanticide in the sense that in female infanticide the girl-child alone, in preference to a son, is killed while infanticide relates with the killing of an unwanted illegitimate child of both the sexes by widows or unmarried mothers. The United Nations has observed that an overwhelming majority of the 117 million "missing girls" in Asia is from India and China (Times of India, 8 October 2011). Articles 315 to 318 of Indian Penal Code define infanticide and female infanticide in India. Article 315 reads, "Whoever before the birth of any child does any act with the intention of thereby preventing that child from being born alive or causing it to die after its birth, and does by such act prevent that child from being born, or causes it to die after its birth, shall, if such act be not caused in good faith for the purpose of saving the life of the mother, be punished with imprisonment of either description for a term which may extend to ten years, or with fine, or with both"; Article 316: "Whoever does any act under such circumstances, that if he thereby caused death he would be guilty of culpable homicide, and does by such act cause the death of a quick unborn child, shall be punished with imprisonment of either description for a term which may extend to ten years, and shall also be liable to fine"; Article 317: "Whoever being the father or mother of a child under the age of twelve years, or having the care of such child, shall expose or leave such child in any place with the intention of wholly abandoning such child, shall be punished with imprisonment of either description for a term which may extend to seven years, or with fine, or with both"; Article 318: "Whoever, by secretly burying or otherwise disposing the dead body of a child whether such child dies before or after or during its birth, intentionally conceals or endeavours to conceal the birth of such child, shall be punished with imprisonment of either description for a term which may extend to two years, or with fine, or with both.” (Gaur, 2004) In a well-known abortion centre in Mumbai, after undertaking the sex determination tests, out of the 15,914 abortions performed during 1984-1985 almost 100 percent were those of girl foetuses (Diaz, 1988). Similarly, a survey report of women's centre in Mumbai found that out of 8000 foetuses aborted in six city hospitals 7999 foetuses were of girls (Gangrade, 1988). In Haryana the sex ratio has decreased from 865 females per 1000 males in 1991 to 861 in 2001. In Punjab, it has gone down from 882 females per 1000 males in 1991 to 874 in 2001 (Times of India, 14 May 2001). The high rate of abortion of female foetus by Indian parents, excluding abortion of illegitimate foetus of either of the sexes, makes them not only a serial killer but their collective crime almost a genocidal act sanctioned by a customary belief in Hindus that a son is essential for salvation (Gautam, 1976).

What is condemnable is not abortion in itself, a right of a parent to deny or accept paternity or maternity, but selective abortion of a foetus of a particular sex. Aborting an unwanted foetus of either sex by a widow, unwed mother or incapable mother is beyond any definition of criminality. Even abortion of foetus of either sex for the purpose of planning a family is not abominable. However, such right of mothers and fathers does not provide excuses for sexually selective homicidal acts ought to be put in category of crime. The contemporary amount of sexual foeticide prevailing in almost all the castes, sects, classes and regions dominated by Hindu ethos is a modern phenomenon in the sense its precursor female infanticide during pre-colonial and colonial period was prevalent mostly among few dominants castes alone (Vishwanath, 1998).

\section{Female Infanticide and Universal Definition of Genocide}

Genocide, indeed, "is a crime under international law", as mentioned in the article 1 of the Genocide Convention (adopted by United Nations on December 9, 1948), Document 9.3 (Duchacek, 1975), according to which it appears that crime of female infanticide committed though in a high amount in India may not be undertaken under international law to prevent and punish the perpetrators of the crime. At the same time killing of a girl child by her own parent is not a crime, "with intent to destroy, in whole or in part, a national, ethical, racial or religious group as such: 1) killing members of the group; 2) causing serious bodily or mental harm to members of the 
group; 3) deliberately inflicting on the group conditions of life calculated to bring about physical destruction in whole or in part; 4) imposing measures intended to prevent births within the group; 5) forcibly transferring children of the group to another group" (Duchacek, 1975). Female infanticide, therefore, does not come under the purview of the proper definition of the genocide as undertaken by the Genocide Convention of December 9, 1948. The international definition of genocide is too restricted and it does not include either political groups (Kakar, 1995) or sexual groups. It is also alleged by certain scholars that "political groups" were not included in the definition of the genocide because of the influence of Stalin (Gellately \& Kiernan, 2003) and (Staub, 1992). Similarly, it may also be alleged that "sexual groups" were not included in the definition because of the patriarchal mindset of the formulators of the definition.

The history of the genocide though goes back to antiquity but it became a crime under international law in 1948 only after introduction of the word genocide in 1944 by Raphael Lemkin (Lemkin, 1946). The concept of "crimes against humanity" has already been introduced into international relations during World War I, when Allied powers alleged massacres within the Ottoman Empire (Schaller \& Zimmerer, 2008). The persecution of Christian minorities including Armenians, Assyrians and Greeks by the Ottomans was declared "a crime against humanity" by the Allied powers (Britain, France and Russia) in a jointly issued statement. Such massacres of various peoples throughout the world and the killing of approximately six million European Jews, three hundred thousand Croatians and massacres of Poles during World War II by the Nazi Germany led by Adolf Hitler prompted United Nations to adopt Convention on the Prevention and Punishment of the Crime of Genocide (CPPCG) in 1948. The question of the killing of girl child by her own mothers, a crime prevailing though in many parts of the world, since antiquity ${ }^{1}$, was not as widely known or studied by then to attract the attention of world leaders to include it also in the definition of the genocide in 1948. However, if humanity is taken as if divided in to two sex based groups ${ }^{2}$, one of male and other of female, everyday killing of girl child in preference to a son in such an amount makes it certainly "a crime against humanity”.

Genocide of Native Americans (Stannard, 1992), (Grenke, 2005), (Cesarani, 2004) the Cherokee deportation (Cater III, 1976), military campaign against the indigenous tribes of Argentina (Rock, 2002), extinction of the Tasmanian aborigines (Blainey, 1980), genocide in Vendee (Secher, 2003), genocide in Philippines (Juan Jr., 2005), the Harero and Namaqua genocide (Cooper, 2006), genocide in Ireland (Coogan, 2002), the Circassian genocide (Leitzinger, 2000), genocide of Armenians, Assyrians, Greeks and Kurds (Totten, Bartrop, \& Jacobs, 2008), holocaust of Zews (Niewyk, 2000), Croatians and Poles (Fein, 1979) and so many other genocidal acts taken together did not extinguish as many human lives as girl children are killed every year in India and China. Indeed, the universal definition of genocide neither including sex as a group nor considering killing of girl children as genocide is outdated and requires reformulation and re-promulgation. It is also at the same time not important whether female infanticide or female foeticide comes under proper universal definition of genocide or not but the actual concern is to accept it or not as "a crime against humanity".

The killing of girl child or abortion of female foetus by her own mother with or without consent of father may conveniently be put under the category of "individual" or interpersonal "homicide", which is not covered under the widely accepted definition of genocide. In a cursory investigation it also appears that it involves a single perpetrator confronting a single victim, which is regarded by many scholars as homicide and not genocide. However, a critical appraisal of such incidents provides an altogether different picture. Though, the incidents are separate but objectives of all those killings are same or may be said to be instigated by one and only customary belief that birth of a male child is a sacrosanct (Kane, 1992) and universally coveted dream of an average Hindu

\footnotetext{
${ }^{1}$ In Preface to the forth edition (1891) of his work, The Origin of the Family, Private Property, and the State: In the Light of the Researches of Lewis H. Morgan, F. Engels has discussed J. F. McLennan' views regarding the growth of exogamous and endogamous marriages among savage, barbarian and civilized peoples. Engels has mentioned at one place, "McLennan argues further: Whence this custom of exogamy? The conceptions of consanguinity and incest have nothing to do with it, for these are things, which developed only much later. But the custom, widespread among savages, of killing female children immediately after birth, might. This custom created a superfluity of men in each individual tribe, the necessary and immediate sequel of which was the common possession of a woman by a number of men-polyandry” (Engels, 1977).

${ }^{2}$ F. Engels has seen man and woman as two separate groups. While writing the history of the growth of monogamy he has written, "Thus, monogamy does not by any means make its appearance in history as the reconciliation of man and woman, still less as the highest form of such (a) reconciliation. On the contrary, it appears as the subjection of one sex by the other, as the proclamation of a conflict between the sexes entirely unknown hitherto in prehistoric times. In an old unpublished manuscript, the work of Marx and myself in 1846. [The reference is to Die Deutsch Ideologie (The German Ideology); English translation of parts I and III published in New York, 1939.] I find the following: 'The first division of labour is that between man and woman for child breeding.' And today I can add: The first class antagonism which appears in history coincides with the development of the antagonism between man and woman in monogamous marriage, and the first class oppression with that of the female sex by the male” (Engels, 1977).
} 
family while coming of a female child in place of a male child is taken religiously, socially and economically unfortunate and hence she is considered either to be killed as a foetus itself or immediately after birth or as sooner it is possible after the birth. The time and procedure of killing the girl child is taken with a consideration to avoid legal action alone. The monolithic objective prompting such killings en masse, though in separate incidents, make it certainly a unified wave of mass murder, sanctified by the customary belief inherited from ancient India through generations after generations. Infanticide was known in ancient India as well as it is mentioned in the religious scripture written by Aapastambha whose time period was probably 500 BC (Kane, 1992).

The religious sanction behind the customary belief, in preference for male child to a female child, has remained instrumental for female infanticides since time immemorial and its generalisation makes it if not genocide than of course a "sacramental" or "customary" genocide. The "sacramental" genocide does not stand for theocratic sanction of infanticide but for the theocratic degraded status of women as sanctified by the religious texts in compliance with her actual social status in family and society. The motherhood of widows and unwed virgins was an act of sin. Many Hindu scriptures declared infanticide as one of the serious sins to be stringently punishable. A scripture by Aapastambha, provided sometime between 400 and $600 \mathrm{BC}$, considered it a grave sin (Kane, 1992). Axiomatic, as it was also an evidence of prevalence of the custom in ancient India in spite of its being an act of sin. The distinction between infanticide and female infanticide is altogether lacking in Hindu religious texts but the enormity of female infanticide as conformed by documentary evidences of colonial India (Vishwanath, 1998) are living testimony of its presence in pre-colonial India.

Though, infanticide was theologically condemned by many religious scriptures (dharmshastras, dharmsutras), religious codes and Puranas, yet there is no reference available in the early colonial documents of state intervention to prohibit such a unified wave of mass murder. Infanticide, as it appears continued throughout the pre-colonial period dominated by various religious states, including Sanatan Hindu, Buddhist, Islamic and Sikh. Without being religiously sanctioned act, all such states tolerated infanticide including female infanticide as being sacramental or customary enough for not to be intervened. Even early colonial administration also was reluctant to intervene in such sacrosanct or customary matters until 1870, when infanticide became a crime inviting penal action. Until then the early colonial administration confined itself to persuading the perpetrators in accordance with the scriptural prohibitions discovered by Orientalists (Vishwanath, 1998). Despite all efforts of colonial state the unified wave of selective mass murder persisted within dominant castes of Hindus of north and west clandestinely under the spell of both spiritual and material greed. Later, the technological innovations, growing perpetual prosperity and cultural Sanskritization (Srinivas, 1966) of dominated castes transformed the sacramental and customary criminality of female infanticide into female foeticide during post-colonial India irrespective of the caste, class or regional variations.

\section{Historicity of Female Infanticide}

In his work, Mother Right published in 1861 Bachofen made a very significant proposition that since humanity lived in a state of sexual promiscuity (hetaerism) the lineage, therefore, could be reckoned only through the female line-mother right-which was the fact for all the humanity of antiquity. The fact of maternity excluded all certainty as regards paternity, and, therefore, women were treated with a high degree of consideration and respect, which also symbolised the rule of women (gynecocracy) (Angels, 1977). There is also reference of such state of sexual promiscuity in Indian mythological epic, Mahabharata, in which Pandu told his wife Kunti that in ancient times women were beyond self-control, leading promiscuous life at will and were kept on changing men (Angels, 1977).

The idea that women were subjugated to men since beginning "is one of the most absurd notions that have come down to us from the period of Enlightenment of the eighteenth century. Woman occupied not only a free but also a highly respected position among all savages and all barbarians of the lower and middle stages and partly even of the upper stage" (Angels, 1977). It is beyond any possibility of existence of female infanticide during the period before replacement of mother right with that of father right.

"The reckoning of descent", Engels wrote, "through the female line and the right of inheritance through the mother were hereby overthrown and male lineage and right of inheritance from the father instituted. As to how and when this revolution was affected among the civilized peoples we know nothing. It falls entirely within the prehistoric times" (Angels, 1977). Engels further wrote, "The overthrow of mother right was the world-historic defeat of the female sex. The man seized the reins in the house also, the woman was degraded, enthralled, the slave of the man's lust, a mere instrument for breeding children” (Angels, 1977). The world-historic phenome- 
non of male revolution overthrowing mother right with that of father right and degrading woman to the state of slavery also found expression in ancient religious scriptures of Hindus, which sanctified necessity of a son for achieving salvation. It is clearly mentioned in Manu Smriti (Code of Manu), "with the birth of elder son man gets redemption from paternal debt, therefore, only elder son has right to inherit his father's property. Only the son with whose birth father gets redemption from paternal debt and gets salvation is a son religiously born, others are kamaj (Born of sexual pleasure or lust)" (Gautam, 1976). At the same time daughters were deprived of her share in father's property (Kane, 1992). The religious and economic futility of daughters, it appears in course of time, made her a liability enough to be killed by her own family at the time of her birth itself. The customary killing of daughters continued throughout pre-colonial period unabated by any state intervention. It continued, though clandestinely, (killing girl child after few years of her birth in place of immediately at the time of birth) even after enactment of Anti-Infanticide Act of 1870 passed during British colonialism. In post-colonial period technological invention of determining sex of foetus began an unprecedented and innovated custom of female foeticide. The origin, nature, procedure and methodology of female infanticide depended upon the existing kind of social relations, social and economic mode of productions and nature of state and technological know how of the Hindu society. The custom of female infanticide, indeed, is historically reliant and not a result of intrinsic violence inherent in human nature.

An act of annihilation of human life by a human being prohibited under an established rule of law may be defined as murder or homicide. If there is no such established rule of law against such annihilation there is any homicide or murder. There is a slight difference between murder and violence. Homicide is historically reliant but violence is intrinsic in human nature. In this sense all violence is not murder. In the paucity of Hindu or non-Hindu state intervention throughout the pre-colonial India infanticide or female infanticide and foeticide was not a crime though not sanctified by the religious scriptures. However, state intervention commenced along passage of Anti-Infanticide Act in 1870 bringing it under the domain of criminality. The crime of infanticide did not stop like crime of Sati, which was completely wiped out during perpetual state vigilance of nineteenth century. In order to avoid legal action the procedure of female foeticide or female infanticide was changed and now the girl child was allowed to grow for some years and then to be killed using various barbaric means. The custom of Sati vanished as it was a visible crime but the invisibility of infanticide allowed it to persist. The very different sacramental nature of colonial state helped diminishing the criminality of sexually selective nature but the amenable sacramental nature of post-colonial state has allowed its own laws to be overlooked.

All history is history of growing liberalisation of relationships among individuals, and, individuals and the state where the nature of individual or state remains constant. "The eighteenth century historians, who recognized that all true history is the history of mankind, assumed that human nature had existed ever since the creation of the world exactly as it existed among themselves" (Collingwood, 2007). The amount of homicide in a given human society in a given time depends upon the degree of liberalisation in the relationships among individuals, and between individuals and state. The historical growth of the idea of tolerance originated and matured in western societies during the age of enlightenment and its propagation in the rest of the world during western colonialism further helped in liberalisation of both kinds of relationships.

In pre-colonial India there was no established rule of law against killing of girl-child and the pre-colonial Indian state preferred carrying the policy of non-intervention in the customary affairs of its religious subjects. The historical growth of the idea of liberalisation among individuals and state resulted into the growth and flowering of the modern values of equality and liberty in the English educated milieu of colonial Indian society, which further manifested in the various social and political movements symbolising eradication of the tradition and custom of Sati immolation ${ }^{3}$, beginning of widow remarriage, prohibition of child marriage, ban on infanticide and female infanticide and eradication of thuggee ${ }^{4}$, etc. The legislations promulgated by the colonial state

\footnotetext{
${ }^{3}$ The term Suttee or Sati was applied to a widow who voluntarily sacrificed herself on the funeral pyre for love of her husband. After the death of her husband the widow was considered as unfortunate and inauspicious, the Suttee by contrast was considered as fortunate and auspicious (Shrama, 1998).

${ }^{4}$ There were number of gangs of thugs or highway bandits involved in killing and looting the carvans of traders. There were several instances of killing and eliminating whole band of carvans of traders. The thugs usually killed their victims by strangulating them with a piece of cloth. Each band of thugs had their own religious traditions though usually most of them worshipped goddess Kali. "Sacrifice is one of the essentials of Shiva worship. Kali is the wife of Shiva, the all destroyer and all-producer. She is the most terrible of all deities in the Hindu pantheon. Her image is that of a female, her colour is black; her tongue protrudes several inches from her mouth. From the lobe of each ear a corpse is suspended and a string of human skulls ornaments her neck and breast. In each of her four hands is the head of a giant while prostrate below her feet lies the body of Shiva her husband” (Somerville, 2000). The thugs operating at the travellers on the rivers were known as water thugs. Until elimination by Sleeman, a British official in the colonial period, thousands of travellers were killed and their corpses buried to avoid detection of the crime each year (Sleeman, 1995).
} 
against such customs succeeded in suppressing immolation of widows in the name of sati and the crime of thuggee but it failed to control customs like female infanticide. In spite of the Female Infanticide Act of $1870^{5}$ passed by the Government to suppress the practice, treating it a murder and punishing the perpetrators of the crime with sentence of death or transportation for life, the crime of murdering their children did not stop. An innumerable number of articles in critical appraisal of the custom and legislation appeared in the newspapers but to no avail. One of them the Urdu Akhbar wrote, "The Infanticide Act of 1870 has not been able to suppress infanticide, but, on the contrary, has tended to make the crime assume a worst aspect. Formerly girls were killed at the very moment of their birth, but now, since the Infanticide Act has come in force, they are allowed to perish from sickness before they attain to the age of a year or two. It will thus be at once perceived that the old practice was less abominable than the present one.”6

In fact, all those motivating modern values imported from western education under the protection of British colonialism always remained alien in the Indian ethos. No sooner the colonialism terminated in the mid-twentieth century all the modern values imported under the influence of colonial State were being eroded and pre-colonial ancient and medieval Indian values began surfacing and replacing these gradually under the governance of native Indian State. It is to be noted here that during British colonialism the maximum punishment for infanticide was punishment of death or transportation for life but now in post-colonial period the maximum punishment is imprisonment for ten years (Gaur, 2004). While there are wide references available regarding sentence of such stringent punishments during colonial period, there is no reference available of any punishment given to perpetrators of the crime of infanticide in independent India. Now, after sixty years of post-colonial caste ridden democratic state formation Indian society has once again began witnessing unprecedented dowry deaths, ever increasing rates of female infanticide and foeticide, caste-based electoral politics, state prohibitions on the freedom of speech and expression, growing ethnic and caste violence, immeasurable state repression and violence, communal riots and re-emergence of all those pre-colonial hibernated values far from being called modern in any sense.

In post-colonial India the female infanticide has crossed all the limits because of the easily available modern technology. UN observation has laid the blame for this phenomenon squarely on the ultra-sonography machine (Times of India, 8 October 2011). In recent past Pre-Natal Diagnostic Centres have mushroomed throughout India, which help in determining sex of foetus that enable people choose to abort female foetus. Such Pre Natal Diagnostic Centres are available in small towns also (Times of India, 14 May 2001). The amount of such violence against girl-child may be witnessed in the latest report of 2011 Census, stating, "The Census also reaffirms another fact-a fact so disturbing that it could cast a shadow on the positive developments: Girls seem to have no place in India's growth story. The data shows that the sex ratio for children below 6 years has dropped from 927 to a dismal 914 girls for every 1000 boys. The gender bias yet again draws attention to a lingering societal flaw that economic growth is not being able to correct” (Times of India, 1 April 2011).

In post-colonial rural India where people do not have access to sex determination facilities, female infanticide is shockingly common. The parents wait until the mother gives birth, and when they find out that a daughter is born, they go ahead and kill the baby by adopting various means such as strangling the baby, giving her poison, dumping her in a garbage bin, drowning her, burying her alive, starving her, stuffing her mouth with salt, or leaving her outdoors overnight so she dies of exposure. What is disturbing is that female infanticide is not considered a crime and rarely do culprits get convicted. Surprisingly, mothers are the ones who often perpetrate the crime, with the support of other women in her network. In post-colonial urban India, educated and fairly wealthy people too often nurse a desire for a male child; and a common practice among them is not to kill the newly born girl child after delivery but to get clinically determined the sex of the foetus during pregnancy itself and to terminate it if it is found to be a female (Tandon \& Sharma, 2006); (Chunkath \& Athreya, 1997); (George, Abel, \& Miller, 1991). Although disclosing the gender of a foetus is illegal, there are numerous doctors who disclose the sex of the foetus for an enhanced fee, and then offer to arrange for the abortion. Thus, although there is a good law in place, its implementation is not as effective as it should be. The Indian Parliament passed the Prenatal Diagnostic Techniques (Regulation and Prevention, of Misuse) Act 57 of 1994 on the recommendation of the joint committee of the House to prohibit pre-natal diagnostic techniques for determination of sex of the foetus to abort (kill) female child. It received the assent of President of India on 20th September, 1994. It is a small Act

${ }^{5}$ Uttar Pradesh State Archives, herein after cited as UPSA: Proceeding No. 4, S. No. 1, File No. 913/1926, No. F/520-25 Judl. dated January 2, 1926, Judicial (Criminal) Dept., May 1926, pp. 15-16.

${ }^{6}$ UPSA: The Urdu Akhbar (Akola) of 17 March 1877, Vernacular Papers, Vol. 10, p. 211. 
consisting of 34 sections divided into VII Chapters (Gaur, 2004).

\section{Female Infanticide in Nineteenth Century India}

Female infanticide and foeticide in post-colonial India is not a modern phenomenon. The custom was very much prevalent in peninsular Gujarat, Punjab and North Western provinces during the pre-colonial India (Wilson, 1855) and (Brown, 1857). Interestingly, the prevailing custom of female infanticide was not uniformly followed either throughout colonial India or throughout all castes ${ }^{7}$. In certain areas and in certain castes the customary killing of daughters was prevailing to the amount beyond imagination. Reports, notes and memoirs of colonial administrators like Jonathan Duncan (1789), Charles Raikes (1855), Rev John Wilson (1855) and John Malcolm (1979-Reprint) provides its prevalence in Jadeja, Jhala, Gohil, Parmar, Rajkumar, Suryavanshi and Jethwa Rajputs, Jats, Ahirs, Lewa Patidars and Kanbis castes of north and west India (Vishwanath, 1998). In a certain village of Humeerpore district in the North Western Provinces later United Provinces the Perihar Tribe of Rajpoots the imbalance in the ratio of boys and girls was too high. An official report provided following data ${ }^{8}$.

\begin{tabular}{cccc}
\hline & & No. of Boys & No. of Girls \\
\hline \multirow{2}{*}{2} & Mulhita Purihar & 124 & 1 \\
& Other Castes & 144 & 105 \\
\multirow{2}{*}{3} & Mujgawan Purihar & 125 & 6 \\
& Other Castes & 161 & 138 \\
4 & Ludowra Purihar & 62 & 0 \\
\multirow{4}{*}{5} & Other Castes & 100 & 94 \\
& Burgurh Purihar & 0 & 0 \\
6 & Other Castes & 30 & 31 \\
& Mugrout Purihar & 8 & 0 \\
7 & Other Castes & 125 & 99 \\
& Chukasee Purihar & 9 & 2 \\
& Other Castes & 179 & 6 \\
\hline
\end{tabular}

The custom of female infanticide continued throughout the $19^{\text {th }}$ century not only in the Purihar community of Rajputs of Humirpur district in particular but in many communities throughout India. In nineteenth century it was believed that India was the only country on the face of the earth where such custom was known to exist ${ }^{9}$. An article on Infanticide mentioned:

"It took its rise in the time of Hindoo Rajahs and Rajpoot Princes, and that in that age it was not regarded as a crime. The general custom was to kill them as soon as they were born by stuffing cow-dung into their mouths.

\footnotetext{
${ }^{7}$ Hinduism is not a monolithic religion like Christianity and Islam. Hinduism, in fact, is a conglomeration of various castes emerged along growth of innumerable professions. Originally during Vedic period of Aryans there were only three castes or Varnas (Colours) —Priests, Warriors and Vaisyas i.e. traders. Later, along with the assimilation of non-Aryans a fourth Varna of Shudras — came into existence. All the individuals involved in various kinds of manual professions were called Shudras divided into various castes depending upon their manual professions. A fifth Varna of Untouchables was also created for castes involved in menial professions. Unlike European Guild System, each caste was subscribed to a fixed profession without any opportunity of mobility within or without his caste acquired through his birth. A Hindu is born with a caste, which he could not renounce in this life. In a vertical hierarchical system of Hinduism each caste is placed between some upper and some lower castes. It is a system based upon inequality. Inter-caste marriages or inter-caste dining was strictly prohibited in the Hindus. The Shudras and untouchables were not allowed even entry in the Hindu temples or worshipping Aryan Gods. It subsequently forced Shudras and untouchables to worship their own gods or deities identified with their own professions or localities. For centuries Shudras and the untouchables were forced to live under the threat of caste based repression and violence, which gave rise to various sects and traditions within Hindu fold.

${ }^{8}$ UPSA: From W. R. Benson, the Officiating Magistrate to F. M. Lind, the Officiating Commissioner, Allahabad Division (No. 6), Dated Camp Moudha, the $27^{\text {th }}$ February 1865, Judicial (Criminal) Department, North-Western Provinces and Oudh, 25 $5^{\text {th }}$ March 1865, Index No. 15-17, Progs. No. 9, Vol. 43, p. 193.

${ }^{9}$ UPSA: The Lawrence Gazette, Vernacular papers, Vol. 4, 1871, p. 303.
} 
But other plans equally barbarous were in fashion. In some cases they were killed by plunging their faces in milk; while in others, they were ruthlessly strangled with a strong chord. In Gujrat, it was customary to place girls after their birth in an earthen pot, and, after covering its mouth with a lid, and making it fast by means of pounded flour, to bury it under ground. But in most cases, they were made to swallow opium, and thus died in much agony. In the district of Khangurh they were killed by means of the juice of the (madar asclepiad gigantean), or by being exposed to cold. In the Punjab, it was the custom among a particular tribe after murdering girls at their birth, to place a piece of Gur (Jaggery) in their mouth, and a roll of cotton in their hand, and repeat the words, feed on the gur, and spin the cotton. Come into the world no more, but send brothers." ${ }^{10}$

The colonial Government's legislative interference in curbing the crime generated a debate among the English educated classes about the causes of the prevailing custom of female infanticide. Many among them even criticised the strict legislative measure adopted by the Government.

Sir T. Madhava Rao, a social reformer wrote: "The custom of widow-marriage does not exist among the Hindus; Hindu widows are therefore naturally tempted to kill their illegitimate children, and being convicted of murder is sentenced to death. The sentence of death in their case is too severe, because their state of mind at the time of committing the crime does not fall short of temporary insanity. This article was published in the journal of the National Society by the late Miss Carpenter. The Supreme Government has called for the opinions of all local Governments and administration on the subject. Women in a state of widowhood are exposed to great temptations. If any one of them proves unable to stand them, and on becoming pregnant procures an abortion, it is obviously unjust to hang her like other murderers." 11

Another vernacular newspaper mentioned the question of heavy expenditure involved in the marriages of Hindu daughters as the cause of female infanticide: "The infanticide is very much in vogue among some tribes, such as Suddhu, Johdi, Sindhu, Gil, Delun, Dhaliwal, \& c., in the Panjab, especially in Ferozpur. If the boys and girls among them were counted the small proportion of the latter to the former would clearly prove the prevalence of this inhuman custom. It is surprising that the Government has not yet adopted any effectual measure to check it. Marriages among the Hindus generally involve heavy expenditure, and this is the chief cause of the evil in question.,"12

The cause behind such a unified wave of mass murder of girl child by the Hindu mothers of colonial nineteenth century India was not confined to the custom of dowry alone but trauma of Hindu widows, not allowed to remarry, practice of hypergamous marriages and the prevailing custom of Sati also made the girl child unwanted in a Hindu family. An article on the practice prevalent in Hindus not to allow their widows to remarriage was considered even more traumatic than burn to kill her at her dead husband's pyre. "That the condition of native widow is most miserable. All their happiness and pleasures vanish with the death of their husbands. In some classes they are not even fed and clothed properly. Surely nothing could be crueler than this. Many widows lead immoral lives, and procure abortions when they become pregnant: some even become professional prostitutes. Natives tolerate such scandals but do not allow them to marry! The non-interference of Government, too, is absurd. It refrains from intervening on behalf of widows, on the ground that compulsory widowhood is a religious institution, but it allowed no such scruple to stand in its way in putting a stop to the customs of sati, infanticide, and others, which were equally based on religious belief. The custom of sati was really not as cruel as compulsory widowhood. All was over in a few short minutes with the woman who burnt herself to death on the funeral pyre of her dead husband; but under the latter institution widows have to endure life-long miseries."13

In post-colonial India though social stigma still exists in widow remarriage or marriage of a divorced women but now remarriage is gradually becoming much popular in all the classes and castes of Hindu society; and the custom of Sati now is heard only occasionally. Still, the female infanticide is gruesomely popular in both rural and urban India. In fact, the Hindus religiously believe that a son is essential for achieving redemption from transmigration of his soul (Gautam, 1976). Hindu's religious dogmas of Justification by son not by daughter inspire them to have at least one son. In matrix of such religious belief a Hindu goes on trying for a son until he finds one. The mothers of such unwanted girls ran the risk of severe ill treatment at their natal homes causing them emotional and mental trauma. There are fairly good examples that a Hindu becomes father of many daughters because of his persistent attempts to find a son; and the financial burden involved in the marriages of

\footnotetext{
${ }^{10}$ Ibid. pp. 303-304.

${ }^{11}$ UPSA: The Safir-i-Hindustan of the $29^{\text {th }}$ September 1877, Vernacular Papers, Vol. 10, pp. 688-689.

${ }^{12}$ UPSA: The Aftabi Panjab of the $14^{\text {th }}$ June 1880, Vernacular Papers, Vol. 13, pp. 408-409.

${ }^{13}$ UPSA: The Azad (Lucknow) of the $30^{\text {th }}$ March 1886, Vol. 19, 1886, p. 273.
} 
those daughters ultimately results in the crime of killing his infant daughters in foetus itself or immediately after her birth. Here, the mother is not as guilty as much is father. Since, the act of actual killing is done mostly by mothers she becomes guilty. In fact, the risk of severe ill treatment at their natal homes involved in becoming mother of such unwanted girls along with an inherent sense of incapability in producing a son induces her to become a guilty mother.

The age-old idea of redemption from transmigration of Hindu soul through a son alone historically created a highly patriarchal Hindu society in many parts of Indian subcontinent where status of a daughter became insignificant in relation to a son. There also remained few areas especially in east India and North East India where because of the historical reasons patriarchy failed to penetrate matriarchal society. In such areas neither status of girl-child is undermined nor there does any evidence of female infanticide exists. Similarly, Buddhism, having no sexual discrimination in its preaching, was originated though in highly caste-ridden northern India, failed to dominate it for a longer time. Buddha rejected the system of hereditary caste. A man's position in society, he maintained, is determined not by birth (jati) but by worth, by conduct (Charana), and by character (Charitra) rather than by descent (Sangharakshita, 1975). It was forced out from the caste-ridden area of its origin by the Hindu Kingdoms to spread elsewhere, mostly, towards eastern parts of India. In such Buddhist dominated areas of eastern India also the status of daughters is not as low as in the caste-ridden parts of Hindu India. Such areas are also free from the custom of female infanticide.

The other cause of such high rate of female infanticide in patriarchal Hindu India was the rural background of most of the Hindu families having landed property, which until recently was to be divided only among the sons of the deceased masters. The covetousness of a fair share in the ancestral landed property, possible only through a son, was not less responsible in the fairly high amount of female infanticide in the rural India. Since Indian urban society was created and depended mostly upon rural India the phenomenon was not less prevalent in urban India also. Even the provision of equal share to the daughters in the father's immovable property enacted in post-colonial India vide Hindu Succession (Amendment) Act, 2005, No. 39 of 2005, enacted on $5^{\text {th }}$ September 2005, in order to amend the Hindu Succession Act 1956, has had no impact on the severity of the crime. Firstly, it is too early to find the actual impact of such legislation against a traditional and age old belief of male succession; secondly, the legislation is not effective, if the rights of female succession might renounce by the daughters herself, which is a more common practice now a day. In many of the cases the daughters relinquish their right of succession in favour of her brothers on the occasion of the division of property after demise of the father.

The sacramental-genocide of girl-child in nineteenth century India continued unabated even in the presence of severest possible punishment awarded to the convict. Sir T. Madhava Rao wrote a paper on the crime of infanticide and its punishments in India in the Journal of the National Indian Association for May 1876. In this paper and also in a separate memorandum subsequently recorded by him he further suggested that the Government of India should call for a report of all cases which within a given period occurred in British India, and in which woman had been executed or transported for life on a charge of murdering their illegitimate children. The attention of the Local Governments and Administration was accordingly invited to the subject ${ }^{14}$. The replies of the same are summarized below. However, the data provided does not distinguish cases of female infanticide from that of infanticide but it does distinguish the areas where female infanticide was not present.

\subsection{Madras}

During a period of ten years 112 cases were tried in the Courts of the Madras Presidency, in which eight women were sentenced to death, 31 transported for life, 54 imprisoned for varying terms of years, and 19 acquitted. The Madras High Court commuted the sentence of death in four cases to transportation for life, and in two cases to imprisonment for certain terms, and they commuted the sentence of transportation for life in two cases to imprisonment for three and seven years respectively. Application was made to the Government of Madras in seven cases for a reduction of punishment, but in only two of these cases the sentence, which was one of transportation for life was, reduced ${ }^{15}$.

\footnotetext{
${ }^{14}$ UPSA: Circular from the Legislative Department to all Local Governments and Administrations, Nos. 563-574, dated the $31^{\text {st }}$ August 1876.

${ }^{15}$ UPSA: Extract from the Proceedings of the Government of India in the Home (Revenue and Agricultural) Department (Judicial), under date Simla the $26^{\text {th }}$ September1879, No. 15/1103-17. Government of the N.-W. Provinces and Oudh in the Judicial (Criminal) Department for the month of January 1901, File No. 142, Proceeding No. 2 (a), S. No. 19. Reply from Government of Madras, No. 2966, dated 19 $9^{\text {th }}$ December 1877, p. 3.
} 


\subsection{Bombay}

In the Bombay Presidency during the five years from 1871 to 1875, 43 cases came up for trial. In 3 of theses sentence to death was passed, in 13 transportation for life, in 19 imprisonments for different terms of years, and in 8 cases the accused were acquitted. In two cases the sentence of death were commuted by the High Court to transportation for life, and in the third case the sentence of death, though confirmed by the High Court, was commuted by the Bombay Government to transportation for life. In one case the accused, sentenced to imprisonment for a certain term, was discharged by the High Court. The Government of Bombay intervened in only three cases, reducing the sentence of transportation for life to imprisonment for a term of years ${ }^{16}$.

\subsection{Bengal}

In Bengal the statistics of five years show the number of cases tried during that period to have been 11. In none of these cases was the sentence of death passed. In ten cases the accused were transported for life, but in two of these the prisoners were acquitted on reference to the High Court. Recommendations were made in two out of the ten cases to the Government of Bengal for remission of sentence and in one of these cases the sentence was reduced to five years while in the other remission were refused ${ }^{17}$.

\subsection{North-Western Provinces and Oudh}

In the North-Western Provinces 19 women were charged with infanticide between the years 1873 to 1876, of whom 17 were sentenced to transportation for life, one to imprisonment for two years, and the remaining one was discharged. In six cases the High Court reduced the sentence of transportation for life to imprisonment for varying terms of years. The number of cases tried in Oudh during five years was 48 . In 30 cases the accused were transported for life. In two cases sentence of death was passed, but in both instances the Judicial Commissioner commuted the extreme sentence to transportation for life. In two out of three cases, referred to the Local Government, the punishment was reduced by the Chief Commissioner, and in one the offender was pardoned ${ }^{18}$.

\subsection{Punjab}

Of the 51 cases which were tried by the Sessions Judge in the Punjab (Panjab) during a period of ten years, the accused were sentenced to death in two cases, transported for life in 30, and in seven of the remaining cases they were convicted of minor charges and imprisoned for shorter terms. The Chief Court reduced the sentence of death to transportation for life in both cases. The court also acquitted one convict sentenced to transportation for life. In two cases, Punjab government commuted the sentence of transportation for life to imprisonment for seven and two years, respectively ${ }^{19}$.

\subsection{Central Provinces}

In the central provinces (excluding the Nerbudda Division for which no return has been received) 27 cases were brought up for trial in the course of ten years. In three cases sentence of death was passed, in 14 transportations for life, in seven imprisonments for varying terms of years, and in the remaining three the accused were acquitted. In one case the sentence of death was carried out, and in the other two cases the Judicial Commissioner commuted the capital sentence to transportation for life. The Judicial Commissioner also reduced the sentence of one prisoner sentenced to transportation for life, and acquitted another prisoner similarly sentenced ${ }^{20}$.

\subsection{British Burma}

The crime of killing an illegitimate child by the mother was almost unknown in British Burmah (Burma, now Myanmar), and in cases of infanticide, which had occurred, extenuating circumstances had always led to large modification of the highest sentence of the law ${ }^{21}$.

\footnotetext{
${ }^{16}$ UPSA: Reply from Government of Bombay, No. 4532, dated $25^{\text {th }}$ July 1877. Ibid. pp. 3-4.

${ }^{17}$ UPSA: Reply from Government of Bengal, No. 3585, dated $31^{\text {st }}$ July 1877. Ibid. p. 4.

${ }^{18}$ UPSA: Reply from Government of North-Western Provinces and Oudh, No. 907 A, dated $21^{\text {st }}$ July 1877. Ibid. p. 4.

${ }^{19}$ UPSA: From Government of the Panjab, No. 413 C, dated $29^{\text {th }}$ January 1879. Ibid. p. 4.

${ }^{20}$ UPSA: From Government of the Central provinces, No. 1052-46, dated 22 ${ }^{\text {nd }}$ March 1877. Ibid. p. 4.

${ }^{21}$ UPSA: From Government of the British Burma, No. 138-106, dated $10^{\text {th }}$ February 1877. Ibid. p. 4.
} 


\subsection{Assam}

The Judges of Sylhet and the Assam Valley districts reported that no cases of the nature in question had come before them ${ }^{22}$.

\subsection{Mysore}

In Mysore 40 cases were reported to have occurred during ten years, in 12 of which the accused were transported for life, 12 were found guilty of higher offences and sentenced accordingly, and the remaining nine were acquitted. The Chief Commissioner was not moved to commute or reduce any sentence ${ }^{23}$.

\subsection{Ajmer and Marwara}

The total number of case tried by the Courts of Ajmer and Marwara from 1862 to 1876 was 13; of these a sentence of transportation for life was passed in one case only, imprisonment for different terms of years in seven cases, and in two cases the accused were acquitted ${ }^{24}$.

\subsection{Hyderabad}

In Hyderabad assigned districts out of 17 cases tried during ten years, in five cases only was a sentence of transportation for life passed, in four cases imprisonment for different terms of years, and in the remaining eight cases the accused were acquitted ${ }^{25}$.

It is evident from the above statement that there were no cases of infanticide found in Assam and British Burma in the nineteenth century. The cultural trait of the state of British Assam now divided into the states of Assam and the north-eastern states of India comprising Arunachal Pradesh, Manipur, Meghalaya, Mizorum, Nagaland and Tripura are quite different than the rest of India. Originally, the people of these areas held animistic beliefs other than those followed in Hinduism, introduced not earlier than $14^{\text {th }}$ century. Christianity was introduced only after colonisation of the area in the later half of the nineteenth century. "Assam being predominantly a land of non-Aryan inhabitants, marriage laws and customs of the Hindu and Hinduised population, might have been greatly influenced by the former" (Choudhury, 1959). At the same time the women of these areas held high status in comparison to their counterparts in rest of the mainland Hindu areas. As against Hindu marriage tradition there was a custom prevailing in Assam known as Capania system, "by which the bridegroom becomes a lifelong member of the bride’s family” (Choudhury, 1959). In the original traditional tribal beliefs of the predominantly matriarchal society there was no possibility of preference for sons over daughters. It is not surprising that criminal customs like female infanticide or infanticide both were unknown in those areas. Similarly, in Burma, sons were not preferred over daughters. It was by enlarge inhabited by Buddhist population where status of women was not low like Hindu dominated parts of India. There was no role of state regulation or state legislation in the complete absence of such customary crimes in Assam and British Burma. It was only because neither the status of women in those societies was traditionally and religiously considered inferior to men nor women were denied property rights. Although married women had no right in the property of her father, the unmarried daughter had a right to share with her brother the immovable property of her parents. Dowry was unknown and legislation for divorce was not complicated. There was no social stigma involved in the re-marriage of a widow (Gait, 1906) and (Hastings, 1951). The most important fact is that in both societies there is no religious belief regarding men's justification by son or essential requirement of a son for his redemption from transmigration of soul. Such religious belief in Hindus of India was not natural but grew historically.

\section{Convictions and Commutations}

It is also evident from the above replies sent by local governments that out of 381 cases of women charged with infanticide, sentence of death was passed in 18 cases and carried out in only three cases; sentence of transportation for life was finally passed in 152 cases, and in the reminder the accused were either acquitted or sentenced to imprisonment for varying terms of years. In 18 cases applications were made to Local Governments and Ad-

\footnotetext{
${ }^{22}$ UPSA: From Government of the Assam, No. 4200, dated $20^{\text {th }}$ November 1877. Ibid. p. 4.

${ }^{23}$ UPSA: From Government of Mysore, No. 3789-4J, dated $14^{\text {th }}$ July 1877 . Ibid. p. 4

${ }^{24}$ UPSA: From Government of Ajmer and Merwara, No. 269, dated $28^{\text {th }}$ April 1877. Ibid. p. 5.

${ }^{25}$ UPSA: From Resident at Hyderabad, No. 13, dated $16{ }^{\text {th }}$ November 1877 . Ibid. p. 5.
} 
ministration for remission or mitigation of sentence, of which 12 applications were either wholly or partially complied with ${ }^{26}$.

Almost all the authorities consulted were of the opinion, "the working of the law of infanticide is not attended with the evils to which Sir Madhava Rao refers, and that no amendment is therefore required." It was argued, "in the case of infanticidal woman transportation for life is preferable to imprisonment because from imprisonment she would return to society a tainted outcaste; but by transportation she is placed in a new sphere, where, if she again gives way to her instincts, there will be no inducement to kill her child.” In regard to the sense of shame, which constituted a strong temptation to infanticide, the principle of Bentham, which permeate the Penal Code, was quoted. According to which the sense of shame was to be met by counteracting dread of a severe and certain punishment. It was also argued that as the section 109 of the Penal Code was framed, a reduction of the punishment in the case of the guilty mother necessarily involved a reduction of the punishment in the case of the abettors of her crime. Finally, it was said that any change of the law as to infanticide necessarily involved a change in the law as to the minor offences of causing (and attempting to cause) miscarriage, and injuring (and attempting to injure) unborn children. That, this would be unwise and uncalled for could be doubted by no one aware of the extent to which abortion was practised in India ${ }^{27}$.

It was resolved, "in preference to carrying out any change in a well-considered law, the object in view may be sufficiently attained by the Judicial authorities submitting all cases in which women are found guilty of murdering their infant children to the Local Government and Administration concerned, with a view to the consideration of the question whether any commutation or reduction of the sentence should be allowed under sections 54 and 55 of the Indian Penal Code, or under section 322 of the Code of Criminal Procedure. It will off course be for the Local Governments and Administration to take such action in cases thus reported as may seem advisable under the particular circumstances of each case; but His Excellency in Council believes that the adoption of this course, which has been suggested by His Honour the Lieutenant-Governor and Chief Commissioner of the NorthWestern Provinces and Oudh, and by the late Chief Commissioner of Ajmer and Merwara (Mr. A. C. Lyall), will sufficiently meet all reasonable requirements."28

One Musammat Sadhin of district Sultanpur was convicted of murdering her infant immediately after its birth by the end of 1882 but the case was not mentioned in the statement submitted by the Inspector-General of Police, North Western Provinces and Oudh ${ }^{29}$. However, on the basis of particulars provided by the Police Administration Report for the year 1882, it was found that the total number of cases of legitimate or illegitimate infanticide in Madras was 13 out of which 7 were convicted of transportation for life and no one's punishment was commuted. In 8 such cases in Bengal the convicts were awarded transportation for life. In North Western Provinces and Oudh 11 were sentenced to transportation for life and sentences of 9 were commuted. The total number of cases of infanticide in Central Provinces was 5, out of which 4 were sentenced transportation for life and the sentence of 3 were commuted. In 2 cases in Coorg the trial was awaited. In the 2 cases of Hyderabad 1 was sentenced to transportation for life and punishment of 2 convicts was commuted ${ }^{30}$. It is evident that out of the total 41 cases of infanticide only 18 guilty mothers were transported for life.

The statement of cases in which women were found guilty of murdering their infant children and which was reported to the Government of North Western Provinces and Oudh during 1884 was sent from IG Police on 12 February 1885. According to this statement the sentence for transportation for life passed on Musammat Rachpali of Gorakhpur Division, on Musammat Sanichari of Ghazipur Division, on Musammat Sanichari of Gorakhpur Division, on Musammat Munia of Gorakhpur Division was modified to 14 years transportation, 12 years transportation, 7 years transportation and 5 years transportation consequently by Local Government. The sentence was allowed to stand in the case of Musammat Bhagwania of Cawnpore Division and no order had yet been passed in the case of Musammat Punni of Shajahanpur Division ${ }^{31}$.

In 1884, the sentence of transportation for life pronounced to all the convicts of infanticide in the five districts

\footnotetext{
${ }^{26}$ UPSA: UPSA: Extract from the Proceedings of the Government of India in the Home (Revenue and Agricultural) Department (Judicial), under date Simla the $26^{\text {th }}$ September1879, No. 15/1103-17. Government of the N.-W. Provinces and Oudh in the Judicial (Criminal) Department for the month of January 1901, File No. 142, Proceeding No. 2 (a), S. No. 19. Ibid. p. 5.

${ }^{27}$ Ibid. pp. 5-6.

${ }^{28}$ Ibid. p. 6.

${ }^{29}$ UPSA: From Secretary to Government, N.-W. Provinces and Oudh, to IG of Police, N.-W. Provinces and Oudh, No. 639, dated Naini Tal, the $13^{\text {th }}$ August 1883. Judicial (Criminal Department, N.-W. Provinces and Oudh, January 1901.

${ }^{30}$ Ibid.

${ }^{31}$ UPSA: Copy of G.O. No. 238/VI-114-2, dated 12 February 1885, Judicial (Criminal) Department, to the Inspector-General of Police, North Western Provinces and Oudh.
} 
of North Western Provinces were modified by the local governments with only one exception. The transportation for life sentenced to Musammat Bhagwania of Cawnpore only was allowed to stand; and in all other cases the sentences was modified by the local governments. Similarly, in the four districts of Oudh, the sentence of transportation for life pronounced for Bachia of Rae Bareli only was allowed to stand; and in all other cases of transportation for life sentenced to Musammat Rukia of Lucknow, Musammat Kailasha of Rae Bareli, Musammat Gobinda of Fyzabad and Musammat Jheria of Sitapur, the sentence was modified to 7 years transportation, 12 years transportation and 5 years rigorous imprisonment by the local governments ${ }^{32}$.

\section{Legal Status in England and Elsewhere}

In 1925, Government of United Provinces when desired of making special provision in the Indian Penal Code to deal with the cases of infanticides, the Government of India enclosed a copy of a letter, dated July 25, 1925, from the Government of Bombay and its enclosures on the subject. It referred the law on the question then in force in England and in certain countries in the continent of Europe. It also mentioned the debate in the House of Lords in 1922 when the Infanticide Act of that year was under consideration. Lord Loreburn proposed, “...to leave it to the Judge and not to the jury to determine whether the matter should be manslaughter or murder." Lord Alverstone proposed, "...to leave the law as it stood and simply to provide that a judge might record the sentence of death instead of pronouncing it in open court." Lord James Hereford proposed, corresponding to those of the Child Murder (Trial) Bill, which was passed in 1922, "where a women was charged with the murder of her infant child and evidence was given that at the time the offence was committed the women had not fully recovered from the effect of giving birth to the child the jury were to be empowered to convict her of manslaughter instead of murder.,33

The relevant provisions of the Act contained in the first two sub-sections of Section 1 run as follows:

"1) Where a woman by any wilful act or omission causes the death of her newly-born child, but at the time of the act or omission she had not fully recovered from the effect of giving birth to such child, and by reason thereof the balance of her mind then disturbed, she shall, notwithstanding that the circumstances were such that but for this Act the offence would have amounted to murder, be guilty of felony, to wit, of infanticide, and may for such offence be dealt with and punished as if she had been guilty of the offence of manslaughter of such child.

2) Where upon the trial of a woman for the murder of her newly-born child, the jury are of opinion that she by any wilful act or omission caused its death, but that at the time of the act or omission she had not fully recovered from the effect of giving birth to such child, and that by reason thereof the balance of her mind was then disturbed, the jury may, notwithstanding that the circumstances were such that but for the provisions of this Act they might have returned a verdict of murder, return in lieu thereof a verdict of infanticide.,”34

Under above provisions the Bill provided that the mother may be dealt with and punished as if she had been guilty of the offence of manslaughter, in which case the punishment was under section 5 of the offences against the Person Act of 1861, at the discretion of the court and may be up to a maximum of penal servitude for life. Lord Birkenhead explained, "the mere fact that the woman had not recovered from effects of childbirth should not be sufficient but that it should also be necessary that the emotional and physical strain should have so deranged those elements in the human mind which lead to action that there should not be a free decision as between the forces of right and forces of wrong.",35

The Government of India, however, observed, "Any amendment of the law in regard to the killing of newlyborn children would of course only provide for the mitigation of the offence if the person killing the child was the mother. It is suggested, however, that the prevalence at any rate until recently, of the practice of female infanticide indicates a danger of modifying the law so as to provide for the mitigation of the offence when the mother commits it. When such a child has in fact been killed by someone else there would perhaps always be a danger of the concoction of evidence to implicate the mother." It was also suggested that the main reason for the legislation of 1922 in England did not exist in India. In India, there was no necessity of going through the farce of imposing the death sentence with the dreadful paraphernalia adopted in England. It was always possible for

${ }^{33}$ UPSA: From H. Tonkinson, Joint Secretary to Government of India to Secretary to the Government of United Provinces, Subject: Infanticide, No. F/529-25 Judl. dated January 2, 1926, File no. 213/1926, Progs. No. 4, Serial No. 1, Judicial (Criminal) Department, May 1926.

${ }^{34}$ Ibid.

${ }^{35}$ Ibid.
} 
the courts to impose the alternative sentence of transportation for life and then it was open to the Executive Governments, in accordance with what was understood to be their normal practice, to reduce the sentence to an appropriate term ${ }^{36}$.

Legitimate or illegitimate infanticide including female infanticide considered though an act of homicide by the colonial government was never considered a severe crime liable for the punishment of death or transportation for life by the local governments during colonial period also. It was not a crime at all during pre-colonial India and even today in the post-colonial period there are no evidences available of punishments to guilty mothers or her husbands and other members of her family responsible for instigating her directly or indirectly to kill her daughters. The patriarchal Hindu mind set was not peculiar in putting the crime of female infanticide upon mothers alone. In all the debates undergoing in England also there is no reference available about convicting the fathers or other family members under whose active instigation the crime was committed by the so called guilty mothers. The prevalence of such patriarchal mind set was responsible in deliberate commutation of punishments to guilty mothers, fathers and other instigator family members under spell of sacramental requirement of sons in preference of daughters, hypergamous marriages and religious sanction of succession through male offspring. The invisibility of criminality is still helping such mind set not to be located and prosecuted. The unified wave of criminality against a particular sex, enhanced under sophisticated technological innovations, contiguous now in almost all the classes and castes of India, dominated by Hindu religious ethos and economic greed, requires rational consideration to accept it as a crime against humanity and undertaking measures to restrain it.

\section{Conclusion}

The religious sanction behind the customary belief of preference for male child to a female child has remained instrumental in the prevalence of the crime of female infanticides, mostly, in those parts of Hindu India where such dogmas are reigning from ancient to modern times. The objective prompting such killings, though in separate incidents, makes it certainly a unified wave of mass murder, which if not considered genocide in generally accepted terminology then may definitely be called sacramental-genocide. Female infanticide throughout precolonial period was not considered as an act of homicide by the State and there was no existing legislation against the customary crime. It naturally at that time though was an act of violence inherent in the human nature but the act was historically reliant and criminal because the crime was induced by the historically evolved religious belief revolving around sacred requirement of a son for the purpose of redemption from transmigration of a Hindu soul and also the material threats coming with the birth of a daughter. However, female infanticide beginning pre-colonial period continued throughout the colonial and post-colonial period. No official measures of legislation succeeded in eliminating completely this criminal tradition of violence against girl-child during colonial period. There were several voices against the custom of sacramental-genocide of girl child in view of the advent of humanist and enlightened values of equality and liberty in the traditional society of Hindus during colonial state. But at the same time the pronouncement of severest punishment of death and transportation for life to guilty mothers were criticised by many. The colonial state interference in the customary violence against the girl child forced the Hindu families to resort to other means of homicide making a unified wave. The murder of girl child during the colonial period was now committed clandestinely as was declared illegal by the colonial state. Similarly, in almost all the cases barring few exceptions the sentences of transportation for life were modified or commuted by the local governments. Post-colonial India witnessed transformation of Indian society along gradual erosion of humanist values under reassertion of native tradition and religious beliefs. Though there are strict legislative measures against homicide of a girl child in post-colonial India also but are completely ineffective in curbing the unified wave of killings of girl children, which is also accelerated by the easily available modern technology. Is it not high time to declare the sexually selective foeticide and female infanticide as a crime against humanity responsible for creating threatening sexual imbalance in many parts of Hindu India?

\section{Acknowledgements}

I am highly thankful to Prof. Eric Johnson, Central Michigan University, USA; and Pieter Spierenburg, Erasmus University, Rotterdam, The Netherlands, for inducting me as Asian Consultant in their joint project, "Global Trajectory of Homicide and Genocide", and for inviting me to present my research papers on Violence in India

\footnotetext{
${ }^{36}$ Ibid.
} 
and Female Infanticide in Nineteenth Century India, at its first, second and fourth meetings at Erasmus University, Rotterdam on 28-29 April 2011; 11-12 November 2011 and York University, UK on 30 November-1 December 2012 consequently.

\section{References}

Blainey, G. (1980). A Land Half Won (p. 75). South Melbourne, Vic: Macmillan.

Brown, J. C. (1857). Indian Infanticide: Its Origin, Progress and Suppression. W. H. Allen \& Co.

Carter III, S. (1976). Cherokee Sunset: A Nation Betrayed: A Narrative of Travail and Triumph, Persecution and Exile (p. 232). New York: Doubleday.

Cesarani, D. (2004). Holocaust: Critical Concepts in Historical Studies (p. 381). Hove: Psychology Press.

Choudhury, P. C. (1959). The History of Civilization of the People of Assam to the Twelfth Century AD. Thesis, London: University of London. (Foreword by A. L. Basham)

Chunkath, S. R., \& Athreya, V. B. (1997). Female Infanticide in Tamilnadu: Some Evidence. Economic and Political Weekly, 32, 22-29.

Collingwood, R. G. (2007). The Idea of History (Revised ed., p. 82). Oxford.

Coogan, T.-P. (2002). The Troubles: Ireland's Ordeal and the Search for Peace (p. 6). London: Palgrave Macmillan Trade.

Cooper, A. D. (2006). Reparations for the Hereto Genocide: Defining the Limits of International Litigation. African Affairs, 106, 113-126. http://dx.doi.org/10.1093/afraf/adl005

Diaz, A. A. (1988). Amniocentesis and Female Foeticide (p. 87). Bulletin of the Indian Federation of Medical Guide.

Duchacek, I. D. (1975). Nations and Men: An Introduction to International Politics (3rd ed., p. 331). Illinois: The Dryden Press.

Engels, F. (1977). The Origin of the Family, Private Property and the State: In the Light of the Researches of Lewis H. Morgan (pp. 13, 65-66). Moscow: Progress Publishing.

Fein, H. (1979). Accounting for Genocide (pp. 79, 105). New York: The Free Press.

Gait, E. A. (1906). A History of Assam. Calcutta: Thacker, Spink \& Co.

Gangrade, K. D. (1988). Sex Determination: A Critique. Journal of Social Change, 18, 63-70.

Gaur, K. D. (2004). A Textbook on the Indian Penal Code (3rd ed., pp. 514-517). Foreword by Justice V. N. Khare, Chief Justice of India, Delhi: Universal Law Publishing Co.

Gautam, C. (Ed.) (1976). Manu Smriti (Chapter 9, Verse 107, 2nd ed.). Bareilly: Sanskriti Sansthan, Khwaza Kutub.

Gellately, R., \& Kiernan, B. (2003). The Specter of Genocide: Mass Murder in Historical Perspective (p. 267). Cambridge: Cambridge University Press. http://dx.doi.org/10.1017/CBO9780511819674

George, S., Abel, R., \& Miller, B. D. (1991). Female Infanticide in Rural South India. Economic and Political Weekly 27, 1153-1156.

Grenke, A. (2005). God, Greed, and Genocide: The Holocaust through the Centuries (p. 161). Washington DC: New Academia.

Hastings, J. (Ed.) (1951). Encyclopaedia of Religion and Ethics, Vol. 2. New York: Charles Scribner's Sons.

Juan Jr., E. S. (2005). We Charge Genocide: A Brief History of US in the Philippines. "Political Affairs," 28 December 2005.

Kakar, M. H. (1995). Afghanistan: The Soviet Invasion and the Afghan Response, 1979-1982. University of California Press, The Regents of the University of California. http://content.cdlib.org/xtf/view?docld=ft7b69pl2h\&brand=eschol

Kane, Dr. Pandurang Vaman (1992). (tr. Arjun Chaube), Dharmashastraka Itihas: Pracheen evam Madhyakaleen Bhartiya Dharma tatha Lok Vidhiyan (History of Religious Scriptures: Ancient and Medieval Indian Religion and Customs) (vol.1 pp. 15, 17, 20). First published in 1962, Lucknow: Uttar Pradesh Hindi Sansthan.

Leitzinger, A. (2000). The Circassian Genocide. The Eurasian Politician, Issue 2.

Lemkin, R. (1946). Genocide. American Scholar, 15, 227-230.

http://www.preventgenocide.org/lemkin/americanscholar1946.htm

Niewyk, D. L. (2000). The Columbia Guide to the Holocaust (p. 45). New York: Columbia University Press.

Rock, D. (2002). State Building and Political Movements in Argentina (pp. 93-94). Palo Alto, CA: Stanford University Press.

Sangharakshita, B. (1975). Ch. VIII: Buddhism. In A. L. Basham (Ed.), The Cultural History of India (pp. 98). Oxford: Oxford University Press. 
Schaller, D. J., \& Zimmerer, J. (2008). Late Ottoman Genocide: The Dissolution of the Ottoman Empire and Young Turkish Population and Extermination Policies-Introduction. Journal of Genocide Research, 10, 7-14. http://dx.doi.org/10.1080/14623520801950820

Secher, R. (2003). A French Genocide: The Vendee. Notre Dame, IN: University of Notre Dame Press.

Shrama, A. (1998). Suttee: Historical and Phenomenological Essays (p. 78). Delhi: Motilal Banarsidas.

Sleeman, W. H. (1995). Rambles and Recollections of an Indian Official (pp. 96-111). Edited by Vincent Arthur Smith, Vol. 1, First Published: Westminster, 1893. New Delhi: Asian Educational Services.

Somerville, A. (2000). Crime and Religious Beliefs in India (p. 149). First Published: Calcutta, 1931, New Delhi: Asian Educational Services.

Srinivas, M. N. (1966). Social Change in Modern India (pp. 67-68). Berkeley, CA: California University Press.

Stannard, D. (1992). American Holocaust: The Conquest of the New World (p. 147). Oxford: Oxford University Press.

Staub, E. (1992). The Roots of Evil: The Origins of Genocide and Other Group Violence (p. 8). Cambridge: Cambridge University Press.

Tandon, S., \& Sharma, R. (2006). Female Foeticide and Infanticide in India: An Analysis of Crimes against Girl Children. International Journal of Criminal Justice Sciences, $1,1$.

Times of India, 1 April 2011.

Times of India, 14 May 2001, p. 10.

Times of India, 8 October 2011.

Totten, S., Bartrop, P. R., \& Jacobs, S. L. (Eds.) (2008). Dictionary of Genocide (p. 19). Santa Barbara, CA: Greenwood.

Vishwanath, L. S. (1998). Efforts of Colonial State to Suppress Female Infanticide: Use of Sacred Texts, Generation of Knowledge. Economic and Political Weekly, 33, 1104-1112.

Wilson, J. (1855). History of Suppression of Infanticide in Western India. Bombay: Smith Taylor. 
Scientific Research Publishing (SCIRP) is one of the largest Open Access journal publishers. It is currently publishing more than 200 open access, online, peer-reviewed journals covering a wide range of academic disciplines. SCIRP serves the worldwide academic communities and contributes to the progress and application of science with its publication.

Other selected journals from SCIRP are listed as below. Submit your manuscript to us via either submit@scirp.org or Online Submission Portal.
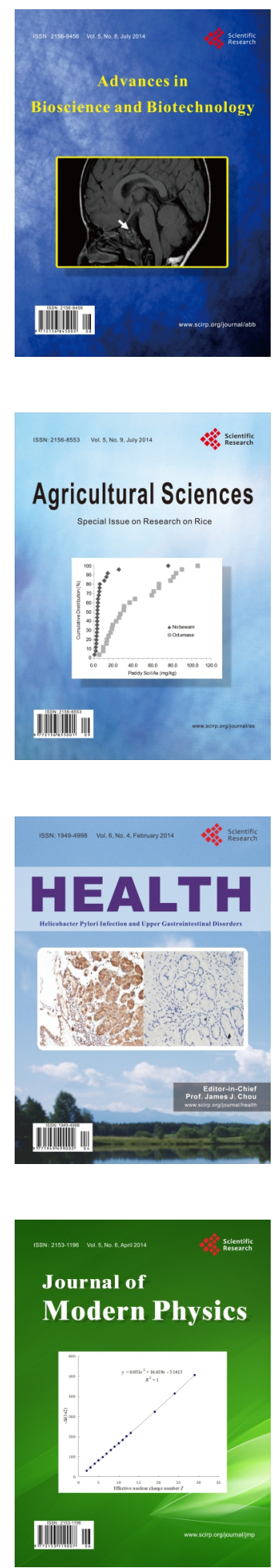
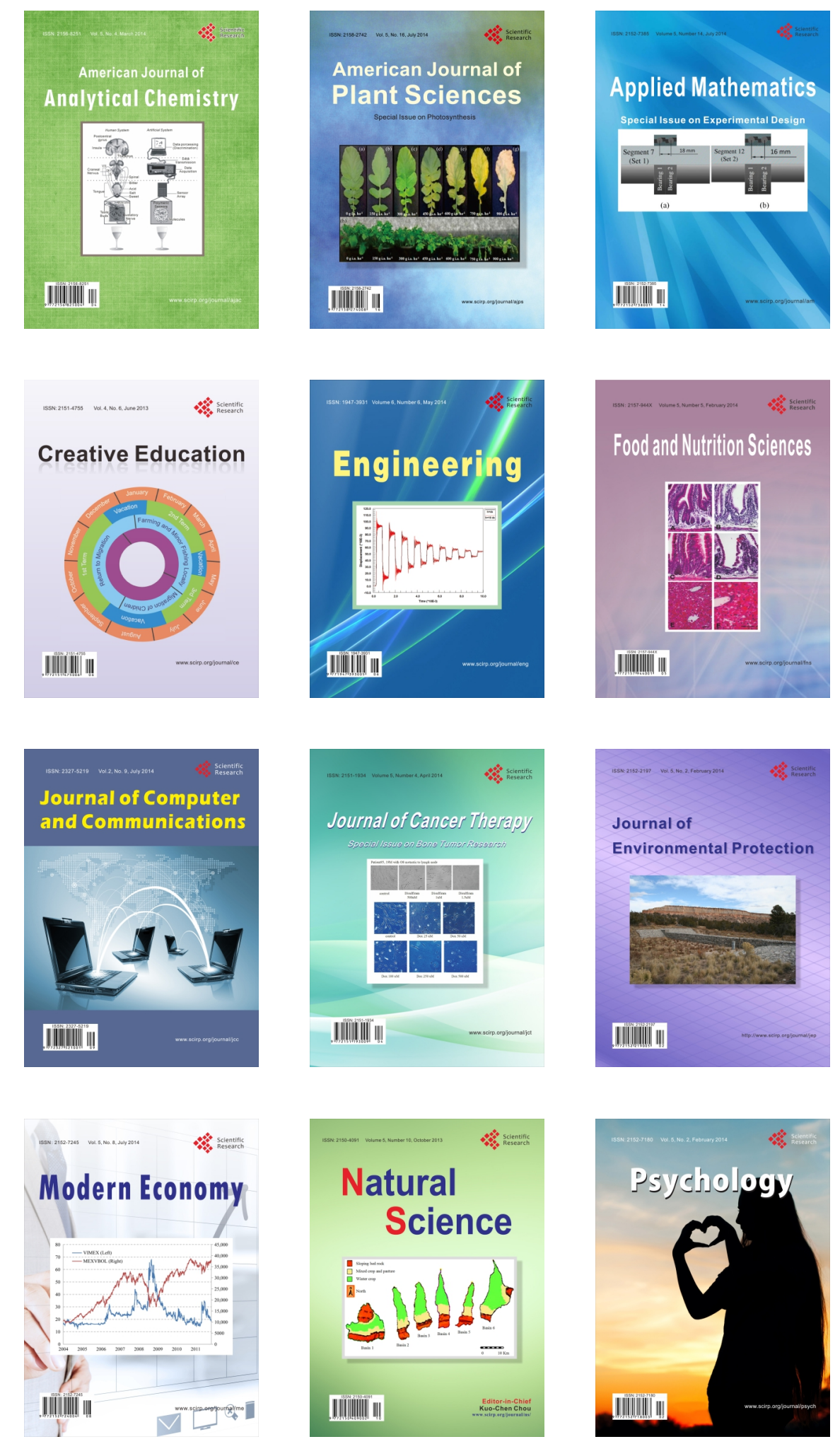